\title{
Diatom grazing by Aegla uruguayana (Decapoda : Anomura : Aegli- dae) : digestibility and cell viability after gut passage
}

\author{
M. Devercelli*, V. Williner \\ Instituto Nacional de Limnología (INALI-CONICET-UNL), José Maciá 1933, Santo Tomé, Santa Fe, CP 3016, Argentina.
}

\begin{abstract}
The aim of this study was to analyse the digestibility and viability of diatoms following gut passage through Aegla uruguayana. Crabs $(\mathrm{n}=28)$ and diatom samples were collected from Las Pencas Stream (Entre Ríos Province, Argentina). Organisms were allowed to graze on the source, then they were placed in aquaria to defecate. Samples of faecal and source material were analysed microscopically to quantify 'live', 'dying' and 'dead' diatoms, and inoculated onto Chu 10-infused agar cultures to observe cell viability. Significant differences were found among source and faeces content of 'live' and 'dead' cells $(\mathrm{p}<0.01)$. Nevertheless, the percentage of digestion after gut passage was only $11.5 \%$. Both agar cultures produced colonies that increased in cell density over time with significantly higher enhancement in faecal treatment $(\mathrm{p}<0.05)$. Evidence of digestion resistance and reproductive stimulation by gut passage could be tested in this experience.
\end{abstract}

Keywords : freshwater anomuran, grazing, gut passage, faeces, cell viability.

\section{Introduction}

Trophic position and interactions of species provide basic information regarding community organisation (Paine 1980). In benthos of shallow streams, the periphyton, mainly composed by algae, bacteria and other eukaryotic microorganisms can be a critical food resource for secondary producers. In particular, algae assemblages play an important role in food web interactions, since they are often the most important primary producers, responsible for carbon fixation and nutrient cycling processes (Vadeboncoeur \& Steinman 2002). Algae constitute a major resource for invertebrates in flowing water ecosystems, even under low biomass due to the high algal turnover rates (McIntire et al. 1996).

The importance of periphyton as a food resource has been depicted in many grazing studies that analysed the gut content of caddisflies (Lamberti et al. 1995), chironomids (Welton et al. 1991), and crayfish (Nynströn et al. 1996). Moreover, these organisms can sub-

\footnotetext{
* Corresponding author :

E-mail: yomimel@yahoo.com.ar
}

stantially constrain the biomass accrual of benthic algae communities and modify their taxonomic structure. It is well known that the most conspicuous algae found in the periphyton are not necessarily the preferred items: grazers can crop over thin layers of diatoms but rarely consume large filamentous green algae (Vinebrooke et al. 2001).

Aegla uruguayana Schmitt is a benthic anomuran, widespread in freshwater systems from Argentina, Uruguay and Brazil (Bond-Buckup \& Buckup 1994). This crab feeds on a wide variety of trophic components and the diversity of its diet spectrum suggests that it is an opportunistic predator. Its diet is mainly composed by plant remains, macroalgae, dipteran larvae, oligochaetes and ephemeroptera (Castro-Souza \& Bond Buckup 2004, Bueno \& Bond-Buckup 2004). In addition, microscope observations of gut content have also shown microorganisms (diatoms, green algae, amoebas, rotifers, tardigrada and acari) ranging from 10 to $500 \mu \mathrm{m}$ (Williner 2003). This variety of small items is explained, in invertebrate grazers by the impossibility of an active choice due to unselective mouthparts and the differences in size scale of prey and grazer (Steinman 1996). Diatoms are also epibionts of the Aegla carapacea and they are removed by the groo-

Article available at http://www.limnology-journal.org or http://dx.doi.org/10.1051/limn/2006011 
ming behaviour. The crista dentata of the third maxillipeds is the part that takes them into the mouth (Martin \& Felgenhauer 1986).

In streams where Bacillariophyceae prevail within benthic algae assemblages, different taxa constitute frequent items in the stomach of $A$. uruguayana (Williner 2003). Nevertheless, microscopic gut content analysis does not give evidence that the ingested cells are digested and assimilated (Porter 1976). Digestibility and biochemical composition are factors determining the nutritive quality of the diet source; the former can be one of the main characteristics for survival and growth of decapods (Mente 2003). The presence of viable algae in faeces demonstrated for copepods (Adrian 1987) and insect larvae (Peterson et al. 1998), suggests that only a part of the total ingest is really utilised as food resource. Nevertheless, gut passage can affect the survival and growth of diatoms and cell viability is not a prerequisite for occurrence in faecal material (Peterson et al. 1998).

The aim of this study was to analyse the digestibility and viability of diatoms following gut passage through Aegla uruguayana. Laboratory experiments were conducted in order to compare diatom content in faecal pellets and source material. Both components were inoculated onto cultures to observed differences in algae growth.

\section{Material and methods}

\section{Study site and sampling}

Las Pencas is a stony stream from the Paraná River floodplain, located at the Entre Ríos Province, Argentina (32 $\left.17^{\circ} 53^{\prime \prime} \mathrm{S}, 60^{\circ} 26^{\prime} 40^{\prime \prime} \mathrm{W}\right)$. The channel longitudinally alternates between deep and broad stretches with rapid water flow and shallow and wide ones with low water flow. The sample site was located at the latter stretch where the mean depth varied between 0.30 and $1 \mathrm{~m}$, and it was $5 \mathrm{~m}$ wide. It presented areas of maximum light penetration and a periphytic community mainly composed by species of epilithic Bacillariophyceae. Sampling was carried out in autumn with a mean water temperature of $19.8^{\circ} \mathrm{C}$; dissolved oxygen was over saturation $\left(9.75 \mathrm{mg} \mathrm{l}^{-1}\right)$; mean conductivity and $\mathrm{pH}$ were $600 \mu \mathrm{S} \mathrm{cm}^{-1}$ and 7 , respectively. Samples of epilithic diatoms were scrubbed off from the upper surfaces of submerged stones with a toothbrush. Specimens of Aegla uruguayana $(n=28)$ were collected by hand. The experiments were conducted at crab inter-molts because the feeding activity surely occurred during the study period.

\section{Laboratory procedures and data analyses}

The organisms were transported to the laboratory at $\pm 24^{\circ} \mathrm{C}$ and kept at a $12: 12 \mathrm{~h}$ light and dark photoperiod. Crabs were placed individually in aquaria with dechlorinated water for $48 \mathrm{~h}$ to clear their guts, and then transferred to flasks containing diatom sample aliquots (source material) to graze. After $14 \mathrm{~h}$ the animals were placed in clean containers to defecate and faeces were posteriorly collected. Samples of faeces and source material were fixed with $4 \%$ formaline and $35 \%$ of the samples were preserved alive in darkness at $4^{\circ} \mathrm{C}$. All the specimens found in a number of transects across the slides were microscopically quantified from counts of at least 100 cells at 400x magnification (Peterson \& Jones 2003). A distinction was done between diatom cell conditions: cells containing full chloroplast ('live cells'), those with reduced or fragmented chloroplast ('dying cells') and empty frustules or individual valves ('dead cells', density calculated dividing by 2 the single valves). The living material was observed $20 \mathrm{~h}$ after collection and the 'live' diatoms were identified by cell displacements. Source samples were cleaned with hydrogen peroxide and washed with deionized water for the identification of diatom assemblage composing the food material. Slides mounted with synthetic resin were examined with a light microscope at 1000x magnification. Taxa were identified according to Krammer \& Lange-Bertalot $(1986,1988)$ and Zalocar de Domitrovic \& Maidana (1997). The 'live', 'dying' and 'dead' diatom contents were expressed as percentage values to allow comparison between gut and source material samples. To confirm that living cells were viable, an inoculum of both source and faecal material was spread onto slides containing Chu 10infused agar medium (Vonshak 1990), producing 4 cultures each. Individual cells (4 to 5 per culture) were located with a microscope at 400x magnification, and coordinates of their position recorded. After 2 and 5 days they were relocated to quantify changes in the size of colonies.

After checking data distribution (Kolmogorov-Smirnov test) and homogeneity of variance (Levene test), a non-parametric pair T-test (Wilcoxon post test) was calculated to detect changes in diatom cell percentages between treatments. Changes in diatom growth were analysed by means of an exponential regression for each culture initiated by both faeces and source material versus time. As a measure of goodness of fit for each case, the coefficient of determination $\mathrm{R}^{2}$ was used. $\mathrm{T}$ test was assessed to determine differences between both cultures (Zar 1996). 
Table 1. Main Bacillariophyceae taxa used as food source for Aegla uruguayana, found in the epilithic community of Las Pencas Stream.

\begin{tabular}{ll}
\hline List of species & \\
\hline Amphora coffeaeformis (Ag.) Kütz. & Navicula reichardtiana Lange-Bert. \\
Amphora copulata (Kütz.) Schoem. \& Arch. & Navicula spp. \\
Amphora pediculus Kütz. & Nitzschia acicularis (Kütz.) W. Smith \\
Capartograma crucicula (Grun.) Ross & Nitzschia apiculata (Greg.) Grun. \\
Cocconeis placentula Ehr. & Nitzschia constricta (Kütz.) Ralf \\
Cymbella cimbiformis Ag. & Nitzschia levidensis (Gru.) Chol. \\
Denticula sp. & Nitzschia linearis W. Smith \\
Entomoneis paludosa (W. Sm.) Reim. & Nitzschia umbonata (Ehr.) Lange-Bert. \\
Fragilaria brevistriata Grun. & Pinnularia gibba var. linearis Hust. \\
Fragilaria construens (Ehr.) Grun. & Pinnularia mesolepta (Ehr.) W. Smith \\
Fragilaria pinnata Ehr. & Rhoicosphenia curvata (Kütz.) Grun. \\
Gomphonema coronatum Ehr. & Stauroneis sp. \\
Gomphonema truncatum Ehr. & Surirella ovallis Bréb. \\
Gyrosigma spenserii (Quek.) Griff \& Henf. & Surirella striatula Turpin \\
Luticola sp. & Surirella tenera Gregory \\
Melosira varians Agardh. & Synedra ulna (Nitzsch.) Ehr. \\
Navicula cryptocephala Kütz. & \\
\hline
\end{tabular}

\section{Results}

Over 33 taxa belonging to Bacillariophyceae were identified from the epilithic community of Las Pencas Stream (Table 1); these constituted the diatom assemblage used as food source for Aegla uruguayana. The comparison of diatom cells in the source material and after gut passage (faecal pellets content) accounted for the differences in terms of physiological conditions (Fig. 1). The content of cells containing chloroplast ('dying' cells and 'live' cells) in crab faeces was $68 \%$, whereas in the source material it significantly increased to $81 \%(\mathrm{p}<0.01)$. The proportion of 'dying' cells was similar in both treatments. On the other hand, the value of 'live' cells was significantly higher in the source material than in the faecal pellets $(\mathrm{p}<0.01)$, being of $33 \%$ and $23 \%$, respectively. In addition, the magnitude of change in the percentage of 'dead' diatoms was higher in faeces $(32 \%)$ than in the source samples $(19 \%)$, and differences were statistically significant $(\mathrm{p}<0.01)$.

The percentage of diatoms digested by Aegla, calculated as the difference between cells containing chloroplast in epilithic community and after gut passage, was $11.53 \%$. The inocula in agar cultures grew and increased in cell density over the 5-day incubation. Cultures initiated from individual cells of faecal samples produced larger colonies than those of source material
(Fig. 2). The former ranged from 4 to 82 cells, whereas the latter produced colonies of up to 8 cells. The T-test showed significant differences between both cultures $(\mathrm{p}<0.05)$. The $\mathrm{R}^{2}$ values of the exponential regression over time for each culture were high, thus indicating a good method calibration. The regression curve was more pronounced in faeces than in source material cultures showing a higher colony size growth.

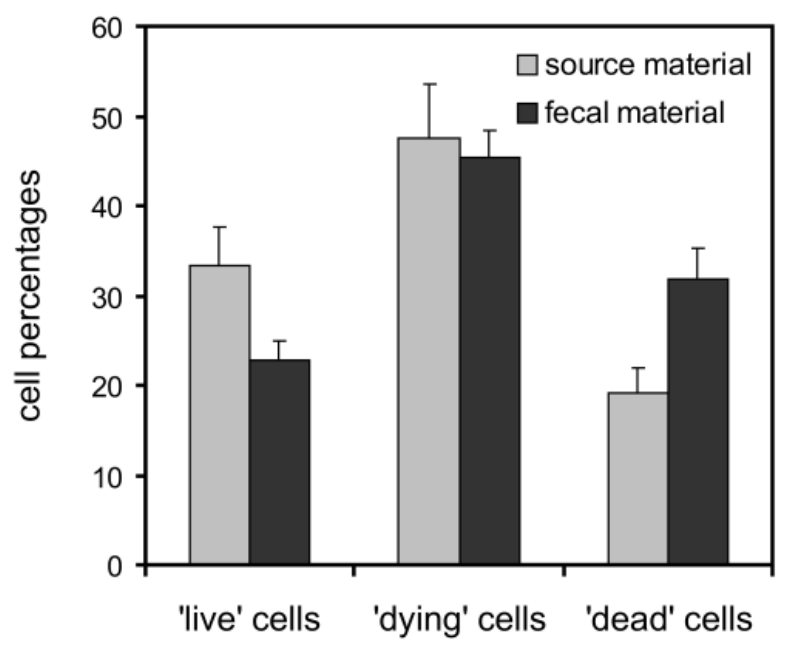

Fig. 1. Percentage of 'live', 'dying' and 'dead' diatoms in source material and faeces contents. 

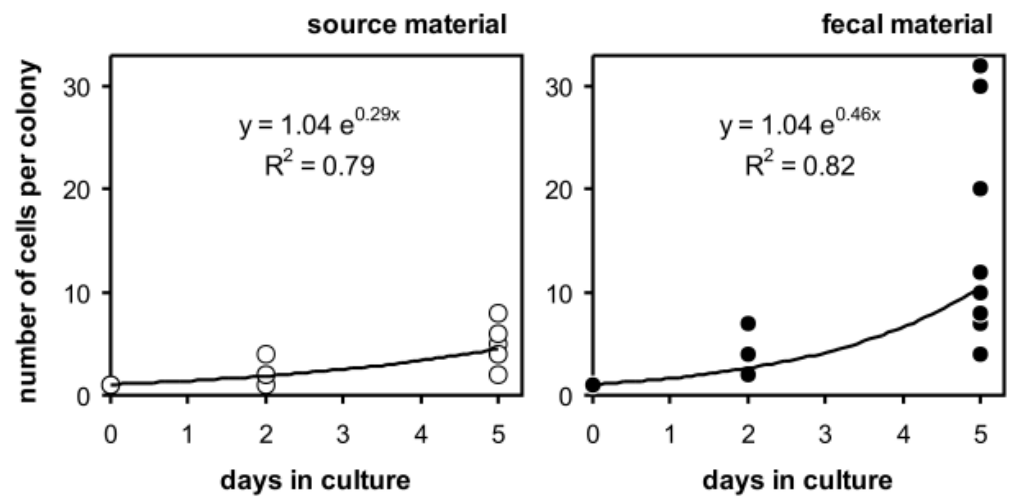

Fig. 2. Changes in diatom colony size (number of cells per colony) on agar cultures, initiated by single cells of source material and faeces, after 2 and 5 days of incubation. In both figures symbols overlap on all days of incubation.

\section{Discussion}

Gut passage induced changes in the diatom physiological conditions as observed by the chloroplast content. Significantly lower percentage of cells with full chloroplast ('live' cells, supposedly in good physiological conditions) and higher percentage of empty frustules or single valves ('dead' cells) were found in faeces as compared with the source material. Similar changes in 'live' and 'dead' cell proportions were found for other algivorous organisms (Peterson et al. 1998). The difference of 'live' cells encountered in the source and faecal samples is translated directly to digestibility, indicating that $12 \%$ of the diatoms ingested by Aegla uruguayana is digested, as it was previously interpreted for other macroinvertebrates (see introduction). The remaining non-digested proportion, clearly demonstrated by the presence of chloroplasts, provides certain evidence of diatom digestion resistance. Reports of intact algal cells in copepod faecal pellets pointed to the fact that the assimilation of ingested food is often incomplete (Reynolds 1984). Hansen \& Josefson (2004) presented evidence that there exist a pool of diatoms that persisted after the ingestion by deposit feeders.

Diatoms differ in their ability to grow in culture from invertebrate faeces and source material (Peterson \& Jones 2003), being significantly higher for the former. The increase in size of the colonies observed in cultures initiated by faecal pellets, indicate that cells remained viable after gut passage. Such growth is an evidence of reproductive stimulation. Therefore, grazing is not an entirely negative process for periphyton. The availability of nutrients during the passage through $A$. uruguayana digestive tracts may benefit algal growth. Gammarus is considered as a stimulator since algae took the nutrition benefit during gut passage (Gladyshev et al. 2000). Cyanobacteria productivity increments in the environment after being fed by Rutilus rutilus (Friedland et al. 2005) could be explained by the enhancement of phosphorus uptake after the passage through fish alimentary canal (Lewin et al. 2003). Other aspect to be considered is that the source samples may contain predators or parasitic organisms, removed from faeces due to conditions created after gut passage, which could be responsible of algal losses in those samples (Reynolds 1984).

In the environment, algae development is also stimulated by habitat facilitation, considered an indirect effect of predator and prey relationship (Liess \& Hillebrand 2004). This phenomenon consists in the grazers' improvement of algae habitat by increasing the availability of space and nutrient regeneration. Defecation returns nutrients to the water, where algae can recycle them. This may be extremely important when the rate of algae growth is severely nutrient-limited (Reynolds 1984). In this study, stomach passage may be considered as another instance of habitat facilitation.

The amount of material and energy contained in faecal pellets presumably remains available for dispersion or as food source for other members of the food web. In this sense, A. uruguayana could be an important agent of propagules dispersion and subsequently, in habitat heterogeneity. This phenomenon could vary due to the substrate characteristics of different parts of the stream, the aggregated distribution patterns of $A$. uruguayana and their preference for certain size of cobbles (Giri \& Williner, unpublished data). Such dispersal mechanisms for algal propagules are common in tadpoles (Peterson \& Boulton 1999) and other macrocrustaceans (Buschmann \& Bravo 1990). 
The consumption of periphyton by grazers in streams directly regulates energy flow to higher trophic levels. These crabs might contribute to structuring littoral communities. The grazing effects could change during annual seasons, partly due to the reproduction movement of adults of A. uruguayana and the recruitment of crab juveniles in some months of the year (Bueno \& Bond-Buckup 2000). Temporal changes in the periphyton community structure could be coupled with these phenomena. Perhaps, reproductive dynamics of diatom assemblages is also associated with the grazing activity effect (Liess \& Hillebrand 2004).

In grazing studies, digestibility is a factor that determines the nutritional quality of microalgae and their utility as food for crabs. A better understanding of the nutritional requirements of freshwater decapods crustaceans is still needed. This study has improved our knowledge on the ecology of the grazing role of $A$. uruguayana. However, questions on decapods biology and the function of gut passage in the autoecology of diatoms are still to be answered.

\section{Acknowledgements}

We are grateful to F. Giri for his help with the statistical analysis, to Dr. I. O'Farrell for the revision of the English version, and to the referees whose comments help to improved the manuscript. This study was supported by 'Programa de Biodiversidad del Litoral Fluvial Argentino' and PICT 01-12678 (SeCyT).

\section{References}

Adrian R. 1987. - Viability of phytoplankton in faecal pellets of two cyclopoids copepods. Arch. Hydrobiol., 110, 321-330.

Bond-Buckup G. \& Buckup L. 1994. - A Família Aeglidae (Crustacea, Decapoda, Anomura). Arq. Zool., 32 (4), 159-346.

Bueno A.A.P \& Bond-Buckup G. 2000. - Dinàmica populacional de Aegla platensis Schmitt, em ambiente natural (Crustacea, Decapoda, Aeglidae). Rev. Bras. Zool., 17, 43-49.

Bueno A.A.P. \& Bond-Buckup G. 2004. - Natural diet of Aegla platensis Schmitt and Aegla ligulata Bond-Buckup \& Buckup (Crustacea, Decapoda, Aeglidae) from Brazil. Acta Limnol. Bras., 16, 115-127.

Buschmann A.H. \& Bravo A. 1990. - Intertidal amphipods as potencial dispersal agents of carpospores of Iridaea lamniariodes (Gigartinales, Rhodophyta). J. Phycol., 26, 417-420.

Castro-Souza T. \& Bond-Buckup G. 2004. - The trophic niche of two sympatric Aegla Leach species (Crustacea, Aeglidae) in a tributary of hydrographic basin of Pelotas River, Rio Grande do Sul Brazil. Rev. Bras. Zool., 21, 805-813.

Friedland K.D., Ahrenholz D.E. \& Haas L.W. 2005. - Viable gut passage of cyanobacteria through the filter-feeding fish Atlantic menhaden, Brevoortia tyrannus. J. Plankton Res., 27, 715-718.

Gladyshev M.I., Emelianova A.Y., Kalachova G.S., Zotina T.A., Gaevsky N.A. \& Zhilenkov M.D. 2000. - Gut content analysis of Gammarus lacustris from Siberian lake using biochemical and biophysical methods. Hydrobiologia, 431, 155-163.

Hansen J.L.S. \& Josefson A.B. 2004. - Ingestion by deposit-feeding macro-zoobenthos in the aphotic zone does not affect the pool of live pelagic diatoms in the sediment. J. Exp. Mar. Bio. Ecol., 308, 59-84.

Krammer K. \& Lange-Bertalot H. 1986. - Bacillariophyceae, 1.
Teil : Naviculaceae. In : Süsswasserflora von Mitteleuropa, Band 2. Gustav Fischer Verlag, Stuttgart \& New York, 876 p.

Krammer K. \& Lange-Bertalot H. 1988. - Bacillariophyceae, 2. Teil : Bacillariaceae, Epithemiaceae, Surirellaceae. In : Süsswasserflora von Mitteleuropa, Band 2. Gustav Fischer Verlag, Stuttgart \& New York, 596 p.

Lamberti G.A., Gregory S.V., Ashkenas L.R., Li J.L., Steinman A.D. \& McIntire C.D. 1995. - Influence of grazers type and abundance on plant-herbivore interactions in streams. Hydrobiologia, 306, 179-188.

Lewin W.C., Kamjunke N. \& Mehner T. 2003 - Phosphorus uptake by Microcystis during passage through fish guts. Limnol. Oceanogr., 48, 2392-2396.

Liess A. \& Hillebrand H. 2004. - Invited review : Direct and indirect in herbivore-periphyton interactions. Arch. Hydrobiol., 159 (4), 433-453.

Martin J.W. \& Felgenhauer B.E. 1986. - Grooming behaviour and the morphology of grooming appendages in the endemic South Americam crab genus Aegla (Decapoda, Anomura, Aeglidae). $J$. Zool. Lond., 209, 213-224.

McIntire C.D., Gregory S.V., Steinman A.D. \& Lamberti G.A. 1996. - Modeling benthic algal communities : an example from stream ecology. Pages 669-704 in Algal Ecology : Freshwater Benthic ecosystems. Stevenson R.J., Bothwell M.L. \& Lowe R.L. (eds). Academic Press, San Diego.

Mente E. 2003. - Nutrition, physiology and metabolism of crustaceans. Science Publishers, Inc. India, $160 \mathrm{p}$.

Paine R.T. 1980. - Food webs : linkage, interaction strength and community infrastructure. J. Anim. Ecol., 49, 667-685.

Peterson C.G. \& Boulton A.J. 1999. - Stream permanence influences microalgal food availability to grazing tadpoles in arid-zone springs. Oecologia, 118, 340-352.

Peterson C.G. \& Jones T.L. 2003. - Diatoms viability in insect fecal material: comparison between two species, Achnanthidium lanceolatum and Synedra ulna. Hydrobiologia, 501, 93-99.

Peterson C.G., Vormittag K.A. \& Valett H.M. 1998. - Ingestion and digestion of epilithic algae by larval insects in a heavily grazed montane stream. Freshwater Biol., 40, 607-623.

Porter K.G. 1976. - Enhancement of algal growth and productivity by grazing zooplankton. Science, 192, 1332-1336.

Reynolds C. S. 1984. - The ecology of freshwater phytoplankton. Cambridge University Press, 384 p.

Steinman A.D. 1996. - Effects of grazers on benthic freshwater algae. Pages 341-373 in Algal Ecology : Freshwater Benthic Ecosystems. Stevenson R.J., Bothwell M.L. \& Lowe R.L. (eds). Academic Press, New York.

Vadeboncoeur Y. \& Steinman A.D. 2002. - Periphyton function in lake ecosystems. The Scientific World, 2, 1449-1468.

Vinebrooke R.D., Turner M.A., Kidd K.A., Hann B.J. \& Schindler D.W. 2001. - Truncated food web effects of omnivorous minnows in a recovering acidified lake. J. N. Am. Benthol. Soc., 20, 629642.

Vonshak A. 1990. - Laboratory techniques for the cultivation of algae117-145 in Handbook of microalgal mass culture. Richomd A. (ed). CRC Press, Florida.

Welton J.S. Ladle M., Bass J.A.B. \& Clarke R. T. 1991. - Grazing of epilithic chiromonids larvae at two different water velocities in recirculating streams. Arch. Hydrobiol., 121, 405-418.

Williner V. 2003. - Ecología trófica del cangrejo Aegla uruguayana Schmitt 1942 (Decapoda : Anomura : Aeglidae). I Jornadas de Ciencias Naturales del NOA y VIII Jornadas de Ciencias Naturales del Litoral, Salta, Argentina, 177 p.

Zalocar De Domitrovic Y. \& Maidana N. I. 1997. - Taxonomic and ecological studies of the Parana River diatom flora (Argentina). Berlin, Stuttgart, $122 \mathrm{p}$.

Zar J.H. 1996. - Biostatistical analysis. Prentice Hall, New York, 918 p. 